\title{
Conhecimentos, Informações e Cultura Geral
}

A revista iniciou seu processo de ampliação da Seção Técnica, conforme anunciado na última edição, publicando neste número sete artigos de caráter técnico-científico ao invés dos tradicionais seis, como de costume. A meta a ser atingida até o final deste ano são oito artigos por edição, fazendo com que a comunidade de polímeros no Brasil e na América Latina passe a ter mais espaço na revista para divulgar seus trabalhos de pesquisa. Aproveitamos a oportunidade para chamar novamente a atenção em relação às alterações realizadas nas Instruções para apresentação de Trabalhos, publicadas no final desta edição, uma vez que, para ampliarmos o espaço da Seção Técnica, foi necessário otimizar a extensão máxima dos trabalhos submetidos.

Adquirir um pouco de cultura geral na área sempre é bom. Na Seção Editorial é apresentada uma matéria mostrando alguns aspectos históricos sobre o desenvolvimento da ciência e tecnologia de polímeros, com alguns detalhes interessantes sobre o surgimento da utilização do termo polímeros, bem como dos desenvolvimentos científico e tecnológico dos primeiros polímeros comercialmente disponíveis.

A Seção Editorial apresenta ainda uma série de relatos de eventos de caráter científico e tecnológico realizados recentemente no Brasil e no exterior, para que os leitores possam conhecer um pouco sobre as novidades apresentadas. Aproveitamos esta oportunidade para agradecer aos redatores dessas notícias e encorajamos todos os leitores a nos enviarem informações sobre os eventos importantes na área de polímeros de que participarem, utilizando os relatos apresentados nesta edição como modelo.

Vários artigos sobre polímeros naturais são apresentados na Seção Técnica, envolvendo polímeros de origem vegetal e animal e mostrando aspectos importantes de sua caracterização e aplicação. São apresentados também nesta seção outros artigos envolvendo a tecnologia de utilização de polímeros sintéticos tais como PET e cristais líquidos poliméricos (LCP).

Lembramos que este ano é muito especial para nossa comunidade de polímeros no Brasil, pois a ABPol comemora 10 anos de existência. Não podemos deixar de participar das atividades de aniversário programadas para o segundo semestre deste ano. 